Notre Dame Law School

NDLScholarship

Journal Articles

Publications

1983

\title{
The Manville Bankruptcy: Treating Mass Tort Claims in Chapter 11 Proceedings
}

Robert Jones

Notre Dame Law School, rjones1@nd.edu

Follow this and additional works at: https://scholarship.law.nd.edu/law_faculty_scholarship Part of the Bankruptcy Law Commons, and the Torts Commons

\section{Recommended Citation}

Robert Jones, The Manville Bankruptcy: Treating Mass Tort Claims in Chapter 11 Proceedings, 96 Harv. L. Rev. 1121 (1982-1983). Available at: https://scholarship.law.nd.edu/law_faculty_scholarship/499

This Article is brought to you for free and open access by the Publications at NDLScholarship. It has been accepted for inclusion in Journal Articles by an authorized administrator of NDLScholarship. For more information, please contact lawdr@nd.edu. 


\section{THE MANVILLE BANKRUPTCY: TREATING MASS TORT CLAIMS IN CHAPTER 11 PROCEEDINGS}

\section{The reorganization petition filed in federal bankruptcy}

court by the Manville Corporation on August 26 , $\mathrm{x} 982,{ }^{1}$ placed a major challenge before the new federal bankruptcy system, which the Supreme Court had recently shaken with its decision in Northern Pipeline Construction Co. v. Marathon Pipe Line $\mathrm{Co}^{2}$ Whereas Congress had foreseen the issues raised by the Northern Pipeline case ${ }^{3}$ when it passed the Bankruptcy Reform Act of ${ }^{1978}$ (BRA), ${ }^{4}$ it did not anticipate that a healthy and solvent corporation ${ }^{5}$ might seek refuge from potentially massive but speculative tort liability in the BRA's chapter I I reorganization provisions. Although Manville and UNR Industries ${ }^{6}$ are the first such apparently healthy corporations

1 In re Johns-Manville Corp., Nos. 82 B Ir,656 to 82 B II,676 (Bankr. S.D.N.Y. filed Aug. 26, 1982).

2 IO2 S. Ct. 2858 (Ig82). The Supreme Court held unconstitutional the new bankruptcy system created by the Bankruptcy Reform Act of 1978 (BRA), Pub. L. No. 95-598, 92 Stat. 2549 (codified at II U.S.C., in scattered sections of 28 U.S.C., and in scattered sections of other titles (Supp. V I $98 \mathrm{r}$ )). The basis of the Court's holding was that, although the bankruptcy courts were established under article I of the Constitution, they were empowered by the BRA to adjudicate matters of private rights over which only article $\mathrm{III}$ courts are to have jurisdiction. IO2 $\mathrm{S}$. Ct. at 287980.

The Supreme Court originally stayed its judgment until October 4,1982 , id. at 2880, and subsequently extended the stay until December 24, I982, to permit Congress to correct the constitutional problem. Northern Pipeline Constr. Co. v. Marathon Pipe Line Co., I03 S. Ct. I99 (r982). Although the December 24 deadline passed without congressional action, this Note does not consider Northern Pipeline's effect on the Manville case; it is assumed that Congress will take action to reconstitute the bankruptcy courts in such a manner that they will be empowered to exercise the same jurisdiction exercised before Northern Pipeline.

3 See Hearings on H.R. 31 and H.R. 32 Before the Subcomm. on Civil and Constitutional Rights of the House Comm. on the Judiciary, 94th Cong., Ist \& 2d Sess. (1975-1976); H.R. REP. No. 595, 95th Cong., Ist Sess. 63-87 (1977), reprinted in 1978 U.S. CODE CONG. \& AD. News 5963, 6023-49.

4 Pub. L. No. 95-598, 92 Stat. 2549 (codified at II U.S.C., in scattered sections of 28 U.S.C., and in scattered sections of other titles (Supp. V r98r)). The BRA, which became effective on October I, 1979, for any bankruptcy proceeding initiated on or after that date, replaced the Bankruptcy Act of I898, ch. 54I, 30 Stat. 544 (codified as amended at II U.S.C., in scattered sections of 28 U.S.C., and in scattered sections of other titles (I976)), and as codified in II U.S.C. is known as the Bankruptcy Code.

5 Manville's financial statements at the time of its chapter II filing showed a net worth (total shareholders' equity) of $\$ 1.2$ billion. Consolidated Balance Sheet Filed with Chapter II Petition, In re Johns-Manville Corp., Nos. 82 B 11,656 to 82 B Ir,676 (Bankr. S.D.N.Y. filed Aug. 26, I982).

6 UNR Industries (Unarco), a codefendant in most of the asbestos-related litigation, is a smaller corporation that produced asbestos only until I962. UNR was actually 
to file chapter II petitions in the face of massive tort claims, manufacturers in a variety of industries that face similar liability could follow suit.

The Manville filing presents a stark contrast to the traditional reorganization case, in which the debtor knows the identities of its creditors and the amount of its debts. In such cases, the debtor seeks the aid of the court only in restructuring its finances and satisfying its existing creditors to the greatest extent possible. The most extraordinary aspects of the Manville case are that the majority of Manville's creditors are unknown and that the majority of the debts on which Manville bases its claims of prospective insolvency are contingent and unliquidated. ${ }^{7}$ Manville thus appears to be attempting to use the bankruptcy power largely as a tool to limit the aggregate size of its current and future liabilities. ${ }^{8}$ If successful, Manville's strategy will have a profound effect on all asbestosrelated tort litigation; Manville is the nation's largest asbestos manufacturer ${ }^{9}$ and the "deepest pocket" 10 among the codefendants in the many asbestos-related suits.

This Note employs the Manville case to examine whether and how the bankruptcy system may appropriately be used by an otherwise solvent company facing massive tort liability. Part I examines the bankruptcy courts' equitable and statutory powers to dismiss reorganization petitions filed in bad faith, and explores both the standards for determining when a petition may be deemed to have been filed in bad faith and the

the first asbestos manufacturer to file a chapter $x$ petition. See In re UNR Indus., Nos. 82-B-984I to 82-B-985x (Bankr. N.D. Ill. filed July 29, 1982 ). Yet another asbestos manufacturer, Amatex Corporation, joined UNR and Manville on November I, 1982. In re Amatex Corp., No. 82-05,220K (Bankr. E.D. Pa. filed Nov. I, 1982).

7 In both the advertisement that appeared in major newspapers the day after Manville's filing, e.g., Wall St. J., Aug. 27, I982, at 29, col. I, and an affidavit filed with Manville's chapter Ix petition, Affidavit Under Local Rule XI-2 of James F. Beasley at 6-7, In re Johns-Manville Corp., Nos. 82 B II,656 to 82 B Ir,676 (Bankr. S.D.N.Y. filed Aug. 26, I982), Manville stated that it is currently defendant or codefendant in approximately 16,500 asbestos-related claims. It further stated that its decision to file under chapter I I was based on a study it commissioned from Epidemiology Resources, Inc., which estimated the minimum number of future lawsuits against Manville at 30,000. See A. Walker, Projections of Asbestos-Related Disease: 1980-2009, at 27 (Epidemiology Resources, Inc., Final Report, Aug. 2, I982). Thus, of the approximately 50,000 present and projected claims on which Manville blames its filing, almost 30,000 have not yet been brought and will be filed (if at all) by unknown plaintiffs, while nearly all 50,000 are contingent and unliquidated.

8 See infra note 54.

9 Greer, Going Bankrupt to Flee the Public, 235 Nation 360 (1982); N.Y. Times, Aug. 27, I982, at 1 , col. 6 .

${ }^{10}$ Manville is ranked 181 ist in the Fortune 500. N.Y. Times, Aug. 27, 1982, at I, col. 6 . 
manner in which those standards should be applied to a Manville-type debtor. ${ }^{11}$ Part II argues that the Manville bankruptcy court has the discretion to dispose of the asbestos claims before it either by estimating each claim individually or by estimating only the aggregate of the claims and leaving individual estimation to other courts. The policies underlying the doctrines of pendent jurisdiction and the right to trial by jury suggest that the bankruptcy court should leave the estimation of individual claims to state courts and other federal courts.

\section{Applying the Doctrine of Dismissal of Bad Faith Reorganization Petitions to MaNVILLE}

The Bankruptcy Reform Act of 1978 reaffirms bankruptcy courts' broad equitable ${ }^{12}$ and statutory powers to deal flexibly with unorthodox bankruptcy petitions by means ranging from dismissal to extraordinary relief. ${ }^{13}$ The new Bankruptcy Code has been interpreted to confer the traditional equitable power ${ }^{14}$ to dismiss petitions filed in bad faith, even though the Code does not explicitly impose a good faith requirement. ${ }^{15}$ The

1 Creditors may also attempt to challenge Manville-type chapter II petitions on the ground that the constitutional bankruptcy power does not extend to healthy, solvent debtors. The leading Supreme Court case addressing this issue, however, is Continental Ill. Nat'l Bank \& Trust Co. v. Chicago, R.I. \& Pac. Ry. (Rock Island), 294 U.S. 648 (1935), which held that the bankruptcy clause should be interpreted very liberally and that the bankruptcy power can extend even to debtors who are solvent in the bankruptcy sense. Id. at $668,672-73$; see infra note 34 . This Note does not address the constitutional issue further, but focuses rather on dismissal for bad faith.

12 The equity powers are reaffirmed most directly in 28 U.S.C. $\$ \mathrm{I} 48 \mathrm{I}$, which provides in pertinent part that "[a] bankruptcy court shall have the powers of a court of equity, law, and admiralty." 28 U.S.C. \& 1481 (Supp. V r98I). In addition, II U.S.C. \$ 105 (a) provides that "[t]he bankruptcy court may issue any order, process, or judgment that is necessary or appropriate to carry out the provisions of this title." II id. $\$$ IO5(a).

${ }^{13}$ See II id. $\$ 305$ (abstention from case); id. $\$ 362$ (d) (lifting or modifying automatic stay); id. $5_{5}$ IO (equitable subordination); $i d$. $\$$ I I I2(b) (dismissal of chapter I I petition or conversion to chapter 7 proceeding); $i d$. \$ I I29 (denial of confirmation of plan not proposed in good faith or not in conformity with other requirements of Bankruptcy Code); id. $\$$ II4I(d)(r) (allowing proponent of plan or court in its confirmation order to deny or modify discharge); 28 id. \$ $147 \mathrm{I}(\mathrm{d})$ (abstention from "a particular proceeding arising under title $I I$ or arising in or related to a case under title II"). As these sections indicate, the courts may exercise some flexibility in taking steps short of dismissal to rectify perceived inequities of either a substantive or a procedural nature.

${ }^{14}$ See, e.g., Sherman v. Collins (In re Collins), 75 F.2d 62 (8th Cir. 1934); Zeitinger v. Hargadine-McKittrick Dry Goods Co., 244 F. 7I9, 722-23 (8th Cir.), cert. denied, 245 U.S. 667 (1917); Gaffney, Bankruptcy Petitions Filed in Bad Faith: What Actions Can Creditor's Counsel Take?, 12 U.C.C. L.J. 205, 2 10-II (I980).

15 Unlike chapter II of the Bankruptcy Code, chapter X of the Bankruptcy Act 
"bad faith" doctrine that was developed at common law has been held to be incorporated into the Bankruptcy Code through section III2(b), which permits bankruptcy courts to dismiss a petition "for cause," whether or not such cause is among the nine explicitly enumerated in section III2(b). ${ }^{16}$

Typically, reorganization cases dismissed for bad faith have been of four types: those in which there is no reasonable chance of successful rehabilitation, ${ }^{17}$ those that attempt to work a

of I898 imposed a requirement that reorganization petitions be filed in good faith. Ir U.S.C. \$ 54I (I976) (amended 1978). Chapter X contained a nonexclusive definition of bad faith in $\$ 146$, I I U.S.C. $\$ 546$ ( 1976 ) (amended 1978 ), a definition that included cases in which it was unreasonable to expect that a reorganization plan could be effected, cases in which the petitioning creditors obtained their claims solely for the purpose of filing the petition, cases in which the interests of creditors and stockholders would be best served by allowing pending litigation of the reorganization issues to go forward in other courts, and cases in which adequate debtor relief would have been available through chapter XI of the Act. Chapter XI of the I8g8 Act contained neither a requirement nor a definition of good faith. See II U.S.C. $\$ \S 70 I-799$ (I976) (amended 1978 ).

16 The provision governing the dismissal of an entire case or the conversion of a chapter II reorganization to a chapter 7 liquidation reads in part:

[O]n request of a party in interest, and after notice and a hearing, the court may convert a case under this chapter to a case under chapter 7 of this title or may dismiss a case under this chapter, whichever is in the best interest of creditors and the estate, for cause, including -

(I) continuing loss to or diminution of the estate and absence of a reasonable likelihood of rehabilitation;

(2) inability to effectuate a plan;

(3) unreasonable delay by the debtor that is prejudicial to creditors;

(4) failure to propose a plan under section II2I of this title within any time fixed by the court;

(5) denial of confirmation of every proposed plan and denial of additional time for filing another plan or a modification of a plan;

(6) revocation of an order of confirmation under section II44 of this title, and denial of confirmation of another plan or a modified plan under section I 29 of this title;

(7) inability to effectuate substantial consummation of a confirmed plan;

(8) material default by the debtor with respect to a confirmed plan; and

(9) termination of a plan by reason of the occurrence of a condition specified in the plan.

II U.S.C. $\$$ III2(b) (Supp. V Ig8I). The courts have read $\$$ III2(b) to permit the dismissal of petitions for lack of good faith. See, e.g., Weathersfield Farms, Inc. v. First Inter-State Bank, 15 Bankr. 282, 283 (D. Vt. 1981); In re Bonded Mailings, Inc., 20 Bankr. 781, 785 (Bankr. E.D.N.Y. 1982); In re Alton Tel. Printing Co., I4 Bankr. 238 (Bankr. S.D. Ill. I98I). Such an interpretation is made possible by $\S$ I02(3) of the Bankruptcy Code, which specifies that the terms "includes" and "including" are not limiting, II U.S.C. § I02(3) (Supp. V I98I), and by the legislative history of $\S$ III2(b). See S. REP. No. 989, 95th Cong., 2d Sess. II7, reprinted in 1978 U.S. CODE CoNG. \& AD. News 5787, 5903; H.R. REP. No. 595, supra note 3, at 406, reprinted in 1978 U.S. CODE CONG. \& AD. NEws at 6362.

17 See, e.g., Fidelity Assurance Ass'n v. Sims, 318 U.S. 608, 615-16 (1943); Weathersfield Farms, Inc. v. First Inter-State Bank, I5 Bankr. 282, 283 (D. Vt. I98I); In re Imperial Heights Apartments, Ltd., I8 Bankr. 858, 863-64 (Bankr. S.D. Ohio I982). 
fraud on the court, 18 those filed to settle internal disputes of a business entity, ${ }^{19}$ and those in which the conduct of the debtor clearly indicates that its sole intent is to hinder or delay its creditors. ${ }^{20}$ Manville's filing does not necessarily fit within any of these categories. First, the strength of Manville's ongoing operations leaves no doubt that a successful reorganization is feasible. ${ }^{21}$ Second, although some asbestos claimants have alleged that Manville has attempted to defraud the court by placing assets in newly created subsidiaries beyond the court's reach, ${ }^{22}$ those allegations remain unproven; in any event, proof of such a segregation of assets would more likely result in the bankruptcy judge's taking control of the segregated assets than in the dismissal of the entire case. Third, Manville's filing is clearly motivated by external problems with creditors rather than by internal squabbles. Finally, although the tort claimants argue that hindrance and delay are indeed Manville's primary motives, courts have generally been reluctant to find such a motive except in the most extreme cases, those in which it appears that delay is the sole reason for the filing. ${ }^{23}$

These four categories are illustrative rather than exclusive; that Manville may not fit neatly within any of them does not mean that its petition may not be dismissed. The underlying inquiry, as in all instances of alleged bad faith reorganization petitions, is whether the debtor "seeks to abuse the bankruptcy law by employing it for a purpose for which it was not in-

18 See, e.g., In re Distillers Factors Corp., I87 F.2d 685, 688-89 (3d Cir. I95I); Zeitinger v. Hargadine-McKittrick Dry Goods Co., 244 F. 719, 722-23 (8th Cir.), cert. denied, 245 U.S. 667 (IgI7); In re PM Properties, I2 Collier BankR. CAS. (MB) 139, I44 \& n.13 (Bankr. C.D. Cal. Mar. 25, 1977).

${ }^{19}$ See, e.g., In re Rice-Varick Hotel, Inc., 184 F. Supp. 864,865 (D.N.H. I959).

$20 \mathrm{See}$, e.g., Shapiro v. Wilgus, 287 U.S. 348,354 (1932); In re 299 Jack-Hemp Assocs., 20 Bankr. 412, 413 (Bankr. S.D.N.Y. I982).

21 A "successful" reorganization is intended here to mean not a reorganization that satisfies every interested party, but rather a reorganization that results in a viable going concern.

22 See Application for Dismissal of Cases or Abstention at 3, I I-13, In re JohnsManville Corp., Nas. 82 B II,656 to 82 B II 676 (Bankr. S.D.N.Y. filed Aug. 26, I982).

${ }^{23}$ See Weathersfield Farms, Inc. v. First Inter-State Bank, 15 Bankr. 282 (D. Vt. I981); Gaffney, supra note 14, at 232-33. This reluctance can be explained by the fact that, although delay can harm creditors, it is an integral part of the reorganization process that serves the desired end of successful rehabilitation. Further, the automatic stay on outside litigation imposed by II U.S.C. $\$ 362$ (Supp. V 1981), see infra note 43, may at times actually work in certain creditors' favor by preventing diligent creditors from obtaining quick and full payment of their claims to the detriment of less vigilant creditors. See H.R. REP. No. 595, supra note 3 , at 340 , reprinted in I978 U.S. CODE CONG. \& AD. News at 6296. 
tended to be used."24 The Bankruptcy Code, however, does not lend itself easily to such an inquiry; ${ }^{25}$ it embodies many varied purposes - protecting jobs, ${ }^{26}$ ensuring a fresh start for debtors, ${ }^{27}$ ensuring equitable treatment for creditors ${ }^{28}$ - designed to benefit debtors and creditors alike. ${ }^{29}$

Manville can argue that filing a chapter II petition at such an early date is entirely consistent with the basic policy of the Bankruptcy Code that encourages debtors to file petitions before their financial position deteriorates to the point at which rehabilitation is no longer feasible, ${ }^{30}$ even if that point would be reached before actual insolvency. ${ }^{31}$ Not only may creditors file involuntary petitions when debtors have waited too long without filing voluntary petitions, ${ }^{32}$ but moreover both section III2(b) of the Code and the case law warn debtors that a petition will be dismissed when there is little or no likelihood of successful rehabilitation. 33

Nonetheless, the absence of a requirement of insolvency as a prerequisite for filing a chapter II petition should not be interpreted to mean that financial condition is not a relevant consideration when evaluating the good faith of such a petition. Moving along a continuum from balance sheet and equitable insolvency ${ }^{34}$ toward perfect financial health, one eventu-

${ }^{24}$ In re Spenard Ventures, Inc., 18 Bankr. $164,166-67$ (Bankr. D. Alaska I982); see Gaffney, supra note 14 , at 224-26.

${ }^{25}$ See Gaffney, supra note 14, at 225.

26 See, e.g., I23 CoNG. REC. 35,446 (r977) (statement of Rep. Edwards).

${ }^{27}$ See S. Rep. No. I 106, 95th Cong., 2d Sess. I (1977); 123 Cong. REc. 35,452 (1977) (statement of Rep. Drinan).

${ }^{28}$ See In re Spenard Ventures, Inc., I8 Bankr. 164, I68 (Bankr. D. Alaska I982); sources cited supra note 27 .

${ }^{29}$ See H.R. REP. No. 595, supra note 3 , at $4-5$, reprinted in 1978 U.S. CODE CONG. \& AD. NEwS at 5965-67; sources cited supra note 27 .

${ }^{30} \mathrm{Cf}$. I23 CoNG. REC. 35,446 (I977) (statement of Rep. Edwards) (Code strongly prefers reorganization over liquidation).

31 See I I U.S.C. $\$$ IOg (Supp. V I98I); 2 Collier ON Bankruptcy II IO9.02 (L. King I5th ed. I982) [hereinafter cited as CoLLIER]. In contrast, both reorganization sections of the old Bankruptcy Act, chapters X and XI, required the debtor to be insolvent in either the bankruptcy sense or the equity sense. II U.S.C. $\$ \$ 530,723$ (1976) (amended 1978); see infra note 34 .

32 Under $\$ 126$ of the old Act, involuntary petitions were authorized in chapter X cases, II U.S.C. $\$ 526$ (1976) (amended 1978), but not in chapter XI cases, see Bankruptcy Act of 1898, \$321, II U.S.C. \$ 721 (1976) (amended 1978). Section 303 of the Bankruptcy Code, II U.S.C. $\$ 303$ (Supp. V Ig8I), expands the use of involuntary petitions by authorizing them in all reorganization cases.

${ }^{33}$ See II U.S.C. § III2(b)(I), (2), (7) (Supp. V I98I); supra note I6; cases cited supra note 17 .

34 There are two distinct types of insolvency: balance sheet insolvency (liabilities exceed assets) and equitable insolvency (inability to pay debts as they come due). The Bankruptcy Code defines "insolvency" in balance sheet terms for general purposes, 
ally reaches a point of relative financial soundness at which application of the bankruptcy laws could not have beer contemplated by Congress. Unfortunately, Congress has never identified the point at which the invocation of the bankruptcy power ceases to be legitimate. ${ }^{35}$ Such line-drawing was left to the courts, to be accomplished by applying equitable principles and the policies of the Code to individual cases. In general, the inquiry should focus on whether the debtor is more likely than not to reach either balance sheet or equitable insolvency in the foreseeable future. ${ }^{36}$

In the Manville case, the court's inquiry should involve a careful scrutiny of the company's present financial condition, projected earnings, and projected asbestos-related liability. The asbestos claimants should be given an opportunity to challenge the findings of the medical study of projected asbestosis occurrence that Manville commissioned ${ }^{37}$ as well as Manville's assessment of its financial condition. ${ }^{38}$ If the creditors

II U.S.C $\$$ IoI(26) (Supp. V I98I), whereas it adopts the equity test for the filing of involuntary petitions, id. $\$ 303(\mathrm{~h})(\mathrm{I})$; see S. REP. No. 989, supra note $\mathrm{I} 6$, at 25,34 , reprinted in 1978 U.S. CODE CONG. \& AD. NEWS at 5811,5820 ; H.R. REP. No. 595, supra note 3 , at 312,323 , reprinted in 1978 U.S. CODE CONG. \& AD. NEWS at 6269,6280 .

35 Section 109 of the Bankruptcy Code, which governs ability to file for bankruptcy relief, imposes no requirements with respect to financial condition. II U.S.C. \& Iog (Supp. V I981).

${ }_{36}$ The bankruptcy court should proceed with such an inquiry into the financial health of the debtor only when creditors request it to do so. See id. \$ III2(b); I24 CoNG. REC. 33,990 (1978) (statement of Sen. DeConcini); supra note 16.

Neither the Bankruptcy Code nor the Bankruptcy Rules indicate where the burden of persuasion lies in a $\$$ III2(b) dismissal hearing. One could argue that, when the financial condition of a company is in question, the burden of proof should lie with that company because it controls all of the necessary information. In the absence of direction from the Code, however, the most reasonable solution may be to place the burden of perstuasion on the moving party. The fact that a debtor such as Manville meets all of the criteria set out explicitly in the Bankruptcy Code to govern who may be a chapter I I debtor, see ir U.S.C. \$ rog (Supp. V I98r), should perhaps create a rebuttable presumption that the debtor belongs in bankruptcy court. But see Transcript of ABC News Nightline, Dec. 27, 1982, at 4 (statement of Judge Dean Gandy, president of the National Conference of Bankruptcy Judges, suggesting that Manville should bear burden of proving future insolvency "by a clear preponderance of the evidence") (on file in Harvard Law School Library).

${ }^{37}$ See A. Walker, supra note 7.

38 There are some doubts concerning the accuracy of Manville's projections of liability and predictions of financial collapse. Not only do plaintiffs dispute Manville's projections of the future incidence of asbestos-related disease, but they also dispute Manville's projections of the amount of assets available to compensate victims. For instance, although Manville hopes to win $\$ 600$ million or more from its insurance companies in pending litigation, see Manville Plans to Seek Strict Limit on its Liability for Asbestos Claims, Wall St. J., Jan. 27, 1983, at 29, col. 4, it has not 
succeed in showing that Manville is more likely than not to remain solvent for the foreseeable future, the reorganization petition should be dismissed as an attempted misuse of the bankruptcy power. If, however, the creditors are unable to show that Manville's projections of future financial ruin are inaccurate, immediate filing would appear necessary to further two basic policies of the Bankruptcy Code - the protection of future claimants and the protection of jobs. Dismissal of Manville's chapter II petition and a return to the status quo would deplete the company's assets and thus prejudice future asbestos claimants unable to execute their judgments fully. ${ }^{39}$ Further, to meet its future liabilities, Manville might be forced to liquidate in full or in part and thereby to eliminate a large number of jobs.

\section{Leaving the Estimation of Individual Claims to State Courts and Other Federal Courts}

If the Manville bankruptcy court determines that the reorganization should proceed, its major task will be disposing of the overwhelming number of tort claims within its jurisdiction. The liquidation of contingent claims is governed by the estimation provision of the Bankruptcy Code, section 502(c). 40 The term "estimation" is misleading insofar as it suggests a mere guess or a lack of procedure; estimation in bankruptcy can be a full adjudication. 41 Normally, the process of estimating individual claims is carried out before the bankruptcy judge. ${ }^{42}$ The unusual nature of the Manville case, however, may permit the bankruptcy court to read section 502(c) in a way that would allow it to lift the automatic stay on outside litigation $^{43}$ and leave the estimation of individual asbestos

included that figure in its projections of its future financial condition. See Application for Dismissal of Cases or Abstention, supra note 22, at I4-15.

${ }^{39}$ See Bulow, Jackson \& Mnookin, Winners and Losers in the Manville Bankruptcy, Wall St. J., Nov. 4, I982, at 30 , col. 3 .

40 II U.S.C. $\$ 502$ (c) (Supp. V I 981 ).

41 See 3 ColliER, supra note $3 \mathrm{I}, 9502.03$. The legislative history of $\S 502(\mathrm{c})$ indicates that the term "estimation" is synonymous with "liquidation." See S. REP. No. 989 , supra note 16 , at 65 , reprinted in 1978 U.S. CODE CONG. \& AD. News at 5851; H.R. REP. No. 595, supra note 3 , at 354 , reprinted in 1978 U.S. CODE CONG. \& AD. NEws at 63 Io.

${ }^{42}$ See, e.g., In re Unit Parts Co., 9 Bankr. 386, 390 (Bankr. W.D. Okla. I98I); 3 Collier, supra note $3 \mathrm{I}, \mathrm{I} 502.03$.

43 To allow litigation to proceed in other federal and state courts, the bankruptcy court would have to lift the automatic stay on litigation involving the debtor that went into effect as soon as the chapter II petition was filed. See II U.S.C. $\$ 362$ (Supp. V Ig8I). The court has the power to lift the stay "for cause." Id. $\$ 362$ (d). 
claims to other courts, as long as the bankruptcy court estimated Manville's total asbestos-related liability, ${ }^{44}$ placed a limit on that liability, and established a compensation fund ${ }^{45}$ for recovery by present and future asbestos claimants.

Under this reading, the bankruptcy court ${ }^{46}$ would estimate Manville's total liability by statistical means. It could employ epidemiological studies to determine the future incidence of asbestos-related disease, and then study the data from the 3500 claims against Manville that have already reached judgment or settlement ${ }^{47}$ to determine the average cost of each claim. ${ }^{48}$ The estimation of Manville's aggregate liability, a process entirely distinct from the estimation of individual claims, would not directly determine the recovery rights of any individual.

Lifting the stay in order to implement this Note's proposal would not violate the stay's purpose, which is to give the debtor a breathing spell from the financial pressures that drove it into reorganization. See S. REP. No. 989 , supra note 16, at 54-55, reprinted in 1978 U.S. CODE CONG. \& AD. NEwS at $5840-4 \mathrm{I}$. The pressure exerted by the asbestos claims would be dispelled by the bankruptcy court's creation of an asbestos compensation fund with a fixed ceiling. The adjudication of individual claims in other courts would pose no additional financial risk to Manville as long as the order granting relief from the stay specified that the plaintiffs would be limited to executing their judgments from the fixed fund.

44 Included in the aggregate estimate would be Manville's projected legal costs to defend the suits. In the 3500 suits that Manville disposed of before its chapter II filing, its total defense costs were nearly equal to the total cost of the judgments rendered against it. See Affidavit Under Local Rule XI-2 of James F. Beasley, supra note 7 , at 5-6.

45 The size of the fund would necessarily be fixed to assure Manville of an upper limit on its liability. The absence of such a ceiling would render the bankruptcy proceeding pointless: it would deny the debtor the "fresh start" so vital to reorganizations, see sources cited supra note 27 , and would violate the "feasibility" requirement of II U.S.C. \$ II2g(a)(II) (Supp. V I98I) by reexposing the debtor to the massive liability that drove it into bankruptcy in the first place.

46 The aggregate estimate would actually be made initially by the proponent of the reorganization plan, presumably Manville itself. In the process of confirming the plan, the court would either accept the estimate or require Manville to alter it. In addition, any class of creditors impaired under the plan could object to the estimate and block the plan by refusing to accept it. See in U.S.C. \$ rizg(a)(7), (8) (Supp. V I 981 ). The asbestos claimants would probably be included within the class of unsecured creditors, unless the court were to find that the claims or interests of the asbestos claimants are not "substantially similar," $i d$. $\$$ I I22(a), to those of the other unsecured creditors. If the only objecting class is the unsecured creditors, the plan could be forced through, with the court's assent, by means of the "cram down" provisions of id. $\$$ In2g(b).

47 See Affidavit Under Local Rule XI-2 of James F. Beasley, supra note 7 .

48 Manville filed a motion on February 3, I983, requesting the bankruptcy judge to make such an aggregate estimate. See Class Action Complaint for Estimation of Contingent Unliquidated Asbestos-Related Health Claims, In re Johns-Manville Corp., Nos. 82 B II,656 to 82 B II,676 (Bankr. S.D.N.Y. filed Aug 26, I982). 
A compensation fund could then be created from Manville's future available assets and revenues. ${ }^{49}$ By comparing the size of the fund to Manville's total estimated tort liability, the court could determine the percentage of each asbestos judgment that could be paid from the fund. 50 Plaintiffs winning judgments in other courts would execute their judgments in the bankruptcy court, from which they would receive payment on a pro rata basis ${ }^{51}$ to ensure that funds be conserved to compen-

49 Manville's epidemiology report estimated that asbestos-related disease would continue to manifest itself over the next 26 years. See A. Walker, supra note 7 , at 25. As in standard reorganization cases, the bankruptcy court would be able to draw on Manville's assets for a few years beyond the filing of the final claim.

${ }^{50}$ Because a reorganization plan may not discriminate among the members of a single class absent express statutory authorization, all unsecured creditors must be treated equally. See II U.S.C. $\$$ II23(a)(4) (Supp. V I98I). Therefore, if the asbestos claimants, assuming that they are deemed unsecured creditors, see supra note 46 , were limited to recovering an amount less than the full value of their claims, the other unsecured creditors would probably be subject to the same limit.

It is unlikely that the asbestos claimants could achieve priority over the other unsecured creditors. The court's exercise of its equitable power to alter the normal scheme of priorities by subordinating one class of claims to another is generally limited to cases in which the holder of the claim being subordinated "is guilty of inequitable conduct, or the claim itself is of a status susceptible to subordination, such as a penalty or a claim for damages arising from the purchase or sale of a security of the debtor." I24 CONG. REC. 33,998 (I978) (statement of Sen. DeConcini); I24 CoNG. REC. 32,398 (r978) (statement of Rep. Edwards); see In re Westgate-California Corp., 642 F.2d I174, 1178 (9th Cir. I981); In re Mobile Steel Co., 563 F.2d 692, 700 (5th Cir. I977).

51 The percentage of each judgment that the bankruptcy court would pay out of the fund would be calculated in a manner similar to that used in the following example. Assume that Manville's total estimated liability is $\$ 2$ billion. Half of that liability, \$I billion, is legal defense costs, and the other half is money damages for plaintiffs. See supra note 44. Assume further that the bankruptcy court determines - that it can create a fund equivalent to $75 \%$ of Manville's total estimated liability, or $\$ 1.5$ billion. Assuming that the legal costs are fixed, only $\$ .5$ billion would be available as money damages to plaintiffs, who would then each be paid one-half of their judgments out of the compensation fund.

Of course, this example does not convey all of the complexities of the process; other factors would necessarily enter into the determination of the percentage of each claim that would be paid out of the fund. For instance, the bankruptcy court may expect Manville to be found negligent in an increasing percentage of its cases as time goes on because of its greater knowledge of the dangers of asbestos when the later plaintiffs were exposed. The court may also choose to err on the low side in the percentage of each judgment that it pays, in order to avoid depleting the fund before all plaintiffs receive some reimbursement. Finally, the court may believe that litigation costs will be altered by increased pressures to settle. See infra note 82 .

The size of the fund available to asbestos claimants depends on the amount of money allocated by the plan to other unsecured creditors and stockholders. The other unsecured creditors will probably be treated equally with the asbestos claimants. See supra note 50. Stockholders, however, have a lower priority than that of unsecured creditors. See, e.g., Julis, Classifying Rights and Interests Under the Bankruptcy Code, 55 AM. BANKR. L.J. 223 (I98I). The creditors could completely block reim- 
sate all future claimants proportionally. ${ }^{52}$ If after several years the court discovered that its estimate of Manville's aggregate liability had been inaccurate, it could readjust the percentage of each claim to be paid out of the fund. ${ }^{53}$

\section{A. The Estimation Requirement of Section 502(c)}

The proposal outlined above would be impossible to implement if the Manville court had no choice under the Bank-

bursement of stockholders by means of the confirmation and "cram down" provisions of II U.S.C. \$ I 29 (Supp. V 1981). See generally Klee, All You Ever Wanted To Know About Cram Down Under the New Bankruptcy Code, 53 AM. BANkR. L.J. I33 (1979) (describing operation of "cram down").

52 Both present and future asbestos plaintiffs should be considered creditors and should be treated alike in all respects. "Creditor" is defined in pertinent part by $\$$ IoI $(9)$ of the Bankruptcy Code as an "entity that has a claim against the debtor that arose at the time of or before the order for relief concerning the debtor." II U.S.C. \$ ror(g) (Supp. V r98I). The future asbestos plaintiffs' status as creditors thus turns on whether their rights to payment can be considered to have "arisen" before the chapter II petition was filed. Each right to payment arguably arose at the time of exposure, before the chapter I I filing, even though statutes of limitations do not generally begin to run until the time of manifestation of the disease. $C f$. Keene Corp. v. Insurance Co. of N. Am., 667 F.2d 1034 (D.C. Cir. 1981) (holding that insurance policies covering workers' exposure to asbestos are triggered at time of exposure as well as time of manifestation), cert. denied, 455 U.S. 1007 (1982).

The cases also indicate that the holders of contingent claims have long been considered creditors for bankruptcy purposes. Under the Bankruptcy Act of 1898 , the holders of some contingent claims were considered creditors even before those claims were expressly made provable by the Chandler Act of 1938 , ch. 575, 52 Stat. 840 (codified in scattered sections of II U.S.C. (1976); repealed 1978); see Maynard v. Elliott, 283 U.S. 273 (I93I); Williams v. United States Fidelity \& Guar. Co., 236 U.S. 549, 556-57 (1915). Under the Bankruptcy Code, contingent claims remain provable; II U.S.C. \$ IOI(4) (Supp. V I98I) includes all contingent claims as "claims" to be dealt with by the bankruptcy courts.

Even if the Manville court were to hold that the future plaintiffs do not fall within the definition of "creditors," the court would be forced to accommodate them in the reorganization plan. Section r 29 (a) of the Bankruptcy Code requires that any plan that the bankruptcy court confirms be "feasible." II U.S.C. \& I I29(a) (Supp. V I98I). Any plan that failed to accommodate future claimants would not be feasible, for it would leave Manville unprotected from an estimated 30,000 post-reorganization lawsuits, see supra note 7 , a situation that would lead inevitably to another financial crisis and force Manville into bankruptcy court a second time. Further, equitable considerations would render such a plan unacceptable. After asserting that the future claimants are its justification for invoking the bankruptcy power, Manville cannot in good faith use that power to exclude those claimants from recovery.

${ }^{53}$ Some would argue that such a system would be unfair, because an adjustment in the percentage of each claim that would be paid from the fund would result in unequal treatment of the claimants; later claimants would receive proportionally more or less compensation than would earlier claimants. This sort of inequality, however, is far more desirable than the alternative, which is to ignore the future claimants and take the risk that, within the fixed fund, there will be no assets at all to compensate them. 
ruptcy Code but to estimate each creditor's claim individually. ${ }^{54}$ Although section 502(c) and the accompanying legislative history seem to suggest that a bankruptcy court must make individual estimates, 55 they do not foreclose a reading that the Manville court need not estimate each claim individually as long as it estimates and places a limit on the aggregate of the creditors' claims. Such a reading would satisfy section 502 (c) on its face, ${ }^{56}$ because an estimation that embodies every single asbestos claim against Manville would occur.

The historical background and policy of section 502(c) support a reading that would permit the bankruptcy court to

54 Manville would clearly prefer to have the bankruptcy court use a panel of experts to estimate individual claims. See Statement of G. Earl Parker, Manville Senior Vice-President, in MacNeil-Lehrer Report, Transcript No. I806, at 4 (Aug. 30, 1982) (on file in Harvard Law School Library). First, Manville would be spared the seven-figure verdicts of "irrational" juries carried away by pity for injured plaintiffs and animosity toward corporate giants. See The Legal Issues in Manville's Move, N.Y. Times, Aug. 27, 1982, at $\mathrm{D}_{4}$, col. I. Experts would be likely to make low estimates because of the sheer volume of the claims coupled with the realization that they were dealing with a single company with limited assets. Id. A panel of experts might also be less likely to assess punitive damages against Manville than a jury would be. In I98I and the first half of $x_{982}$, Manville was assessed punitive damages in Io separate cases averaging $\$ 6 \pm 6,000$ per case. See Affidavit Under Local Rule XI-2 of James F. Beasley, supra note 7, at 6 (listing figures and expressing Manville's concern over punitive damage awards).

55 Section 502(c) of the Bankruptcy Code provides: "there shall be estimated for purpose of allowance under this section - $(\mathrm{I})$ any contingent or unliquidated claim, fixing or liquidation of which, as the case may be, would unduly delay the closing of the case." II U.S.C. $\$ 502$ (c) (Supp. V I98I) (emphasis added). The legislative history of $\S 502$ (c) provides in pertinent part: "This subsection requires that all claims against the debtor be converted into dollar amounts." S. REP. No. 989 , supra note 16 , at 65, reprinted in 1978 U.S. CODE CONG. \& AD. NEWS at 585 I H.R. REP. No. 595, supra note 3 , at 354 , reprinted in 1978 U.S. CODE CONG. \& AD. NEwS at 63 ro. (After these reports were written, $\$ 502$ (c) was restricted somewhat with respect to equitable claims, but the change is not relevant to claims for money damages.)

Nothing in the legislative history indicates that Congress foresaw the predicament in which Manville placed the bankruptcy court. See S. REP. No. 989, supra note I6, at 65 , reprinted in 1978 U.S. CODE CONG. \& AD. NEws at 585I; H.R. REP. No. 595, supra note 3 , at 354, reprinted in 1978 U.S. CODE CoNG. \& AD. NEws at 63ro; I24 Cong. Rec. 33,992, 33,996 (1978) (statements of Sen. DeConcini); I24 Cong. REC. 32,393, 32,397 ( 1978 ) (statements of Rep. Edwards). It is also noteworthy that the proposed Bankruptcy Rules contain no provision for the method of estimating claims. The drafters of the Rules, like Congress, seem to have failed to anticipate the Manville-type situation.

56 See supra note 55 . The terms "any" in $\S 502(\mathrm{c})$ and "all" in the legislative history, see id., arguably are ambiguous, definitely more so than other terms that could have been used, such as "each claim." See also 3 Collier, supra note $3 \mathrm{I}$, I 502.03 , at 502-66 (indicating that $\$ 502$ (c) may accommodate "the potentiality of having another forum continue the process of liquidation if suit had been pending there"). 
estimate only the aggregate of claims. The old Bankruptcy Act permitted courts to decline to allow claims "not capable of liquidation or of reasonable estimation" or whose liquidation or estimation "would unduly delay the administration of the estate or any proceeding under this Act." 57 The new requirement that the court estimate all claims is one of many reforms in the Bankruptcy Code that are intended to implement the Code's broad policy of affording the debtor the most complete relief and the freshest start feasible by disposing of all possible claims during the bankruptcy proceeding. ${ }^{58}$ Congress wished to eliminate the possibility that after the completion of reorganization the debtor would still be faced with the uncertainty of contingent debts that could ruin the financial stability achieved in the reorganization proceedings. ${ }^{59}$ Congress' goals would be achieved equally well by assigning a dollar value to the whole of the asbestos plaintiffs' claims as by assigning a dollar value to each individual claim. In either case, Manville would exit from the reorganization certain of all of its liabilities and able to carry on its business without the fear that pending or future asbestos-related claims would endanger its financial condition.

\section{B. Class Actions}

In deciding whether the Manville court, in applying section 502(c), should estimate each individual claim or should estimate only the aggregate of the creditors' claims and leave the estimation of individual claims to other courts, one must first consider how the estimation of individual claims would be managed in the bankruptcy court. If the bankruptcy court were unable by means of class proceedings to eliminate the need for individual adjudications and were thus forced to conduct many thousands of individual proceedings, a strong case could be made that it should leave such determinations to be spread among a number of other courts.

Because the Bankruptcy Rules incorporate rule 23 of the Federal Rules of Civil Procedure, ${ }^{60}$ a bankruptcy court is unable to certify a class unless it meets the criteria of both rule

57 II U.S.C. $\$ 93$ (d) (1976) (repealed 1978). Claims disallowed under $\$ 57 \mathrm{~d}$ were deemed unprovable and were exempted from discharge; they could be litigated at a later date and would be unaffected by the bankruptcy proceedings. See 3 Collier, supra note $3 \mathrm{I}, 9502.03$.

s8 Cf. II U.S.C. \$ Ior(4) (Supp. V rg8I) (expanding the definition of "claim" in order that more creditors may fall within the purview of the bankruptcy court).

59 See sources cited supra note 27.

${ }^{60}$ See BANKR. R. 723, II U.S.C. app. at 1349 (1976); BANKR. R. 7023 (Preliminary Proposed Draft rg82). 
23 (a) and one of the subsections of rule $23(\mathrm{~b})$. Federal courts have been extremely reluctant to certify classes under rule 23 in mass accident cases, ${ }^{61}$ including the very type of asbestos litigation involved in the Manville case. ${ }^{62}$ Courts have been especially hesitant to certify mass accident classes under rule ${ }^{23}(\mathrm{~b})(\mathrm{I}) .{ }^{63}$ Rule $23(\mathrm{~b})(\mathrm{I})(\mathrm{A})$ has generally been restricted to cases in which equitable, as opposed to legal, remedies are sought. ${ }^{64}$ Rule $23(\mathrm{~b})(\mathrm{I})(\mathrm{B})$, designed for situations in which individual adjudications by some class members would impair the interests of other class members, ${ }^{65}$ has generally been limited to cases in which the impairment is strictly monetary. 66 In the Manville case, the problem of monetary impairment resulting from the limited nature of the available funds would be solved by the bankruptcy court even if no class action were employed; the reorganization plan would provide for only a partial payment of present claims in order to preserve funds for future claimants.

In the few mass accident cases in which $23(\mathrm{~b})(\mathrm{r})$ classes have been certified for plaintiffs seeking money damages, the injuries - resulting from a nightclub fire, ${ }^{67}$ an airplane crash, ${ }^{68}$ and food poisoning on a steamship ${ }^{69}$ — were all caused by a single, sudden event. The Manville case differs sharply from these cases in a manner that makes class treatment less practical and desirable: the causation issue in Man-

${ }^{61}$ See, e.g., 3 B J. Moore \& J. Kennedy, Moore's Federal Practice $\{23.02$ [2.18] (2d ed. 1982); Note, Class Certification in Mass Accident Cases Under Rule $23(b)(I)$, 96 HARV. L. REV. II43, II5I, II53 (I983).

62 See Yandle v. PPG Indus., 65 F.R.D. 566 (E.D. Tex. 1974).

${ }^{63}$ See, e.g., Abed v. A.H. Robins Co., 693 F.2d 847 (9th Cir. 1982), cert. denied, 5 I U.S.L.W. 3552 (U.S. Jan. 24, I983); Note, supra note 6I, at II53. Rule 23(b)(I) provides that a class action may be maintained if the prerequisites of rule 23 (a) are met and, in addition, the following condition is satisfied:

(I) [T]he prosecution of separate actions by or against individual members of the class would create a risk of

(A) inconsistent or varying adjudications with respect to individual members of the class which would establish incompatible standards of conduct for the party opposing the class, or

(B) adjudications with respect to individual members of the class which would as a practical matter be dispositive of the interests of the other members not parties to the adjudications or substantially impair or impede their ability to protect their interests ....

FED. R. CIv. P. $23(b)(r)$.

64 See McDonnell Douglas Corp. v. United States Dist. Court, 523 F.2d 1083, I086 (9th Cir. 1975), cert. denied, 425 U.S. 9II (I976).

65 See Larionoff v. United States, 533 F.2d 1167 , I I8I n.36 (D.C. Cir. 1976), aff'd, 431 U.S. 864 (1977); supra note 63.

${ }^{66}$ See Note, supra note 6I, at Ir 55 n.5 I (collecting cases).

67 Coburn v. 4-R Corp., 77 F.R.D. 43 (E.D. Ky. 1977).

68 In re Gabel, 350 F. Supp. 624 (C.D. Cal. I972).

69 Hernandez v. Motor Vessel Skyward, 6I F.R.D. 558 (S.D. Fla. 1974), aff'd mem., 507 F.2d 1278 (5th Cir. 1975). 
ville is far more complex, involving exposure at many different locations and times and in a variety of circumstances. ${ }^{70}$.

Class certification under rule $23(\mathrm{~b})(3)^{71}$ is even more unlikely than certification under rule $23(\mathrm{~b})(\mathrm{I}) .{ }^{72}$ The primary reason for courts' reluctance to certify classes under rule $23(\mathrm{~b})(3)$ is the weight that $23(\mathrm{~b})(3)(\mathrm{A})$ places on plaintiffs' interest in "individually controlling the prosecution or defense of separate actions." 73 When serious personal injuries or death have been the subject of litigation, courts have found a strong interest in individual control. ${ }^{74}$ In addition, some courts have hesitated to certify classes when the members' claims have been a mix of wrongful death and personal injury claims, ${ }^{75}$ as is true in the Manville case. Finally, not all of the Manville plaintiffs are yet known. Because rule $23(\mathrm{~b})(3)$ includes an opt-out provision, ${ }^{76}$ a resolution of the case cannot bind any plaintiff who did not receive notice and an opportunity to opt out. ${ }^{77}$ This provision would exclude future plaintiffs from the class and would result in a proliferation of classes by requiring the court to certify new classes periodically as new injuries manifested themselves.

The one case similar to Manville in which a class has been certified under rule $23(\mathrm{~b})(3)$, Payton v. Abbott Labs, ${ }^{78}$ demonstrates the futility of employing class treatment in the Manville case. In Payton, which involved women injured in various

${ }^{70} \mathrm{Cf}$. Abed v. A.H. Robins Co., 693 F.2d 847,853 (9th Cir. I982) (drawing same distinction between cases cited supra notes $67-69$ and Dalkon Shield litigation in the process of denying $23(\mathrm{~b})(\mathrm{r})$ class certification to Dalkon Shield plaintiffs), cert. denied, 51 U.S.L.W. 3552 (U.S. Jan. 24, 1983 ).

11 Rule $23(b)(3)$ provides for maintaining an action as a class action when the prerequisites of rule $23(\mathrm{a})$ are met and the following conditions are satisfied:

[T] the class predominate over any questions affecting only individual members, and that a class action is superior to other available methods for the fair and efficient adjudication of the controversy. The matters pertinent to the findings include: (A) the interest of members of the class in individually controlling the prosecution or defense of separate actions....

FED. R. CIV. P. 23(b)(3).

72 Certification under rule $23(\mathrm{~b})(2)$ is not even a possibility; rule $23(\mathrm{~b})(2)$ is restricted to cases in which plaintiffs seek primarily injunctive, as opposed to monetary, relief. See FED. R. CIv. P. 23 advisory committee note, reprinted in 39 F.R.D. 95, I02 (rg66).

${ }^{73}$ FED. R. Crv. P. $23(\mathrm{~b})(3)(\mathrm{A})$.

74 See, e.g., Abed v. A.H. Robins Co., 693 F.2d $847,852-53$ (9th Cir. 1982), cert. denied, 5 I U.S.L.W. $355^{2}$ (U.S. Jan. 24, I983); Hobbs v. Northeast Airlines, 50 F.R.D. 76,79 (E.D. Pa. 1970).

${ }^{75}$ See Yandle v. PPG Indus., 65 F.R.D. 566, 569-72 (E.D. Tex. 1974); Daye v. Pennsylvania, 344 F. Supp. 1337, I342-43 (E.D. Pa. 1972).

${ }^{76}$ See FED. R. CIV. P. 23(c)(2).

77 See Eisen v. Carlisle \& Jacquelin, 417 U.S. 156 (1974).

${ }_{78} 83$ F.R.D. 382 (D. Mass. 1979). 
ways over a span of many years by in utero exposure to the drug. DES, the plaintiff class was restricted to issues of liability ${ }^{79}$ and was confined to Massachusetts residents. ${ }^{80}$ In Manville, issues such as causation and damages also vary with each plaintiff: plaintiffs were exposed to asbestos in different plants, at different times, and under different circumstances, and their injuries vary in both type and severity. Furthermore, various state negligence and strict product liability regimes apply different standards of conduct and liability to defendants. Therefore, the bankruptcy court would be limited to certifying separate subclasses for each distinct state law regime, and each subclass would in turn be limited to litigating common issues of liability as were the plaintiffs in the Payton case. The bankruptcy court would still face individual litigation of causation and damages issues. Not only would it be undesirable for a bankruptcy judge with limited experience managing class actions to tackle a class action of Manville's magnitude and complexity, but moreover one may doubt whether the court would be able to manage the enormous number of individual causation and damage adjudications that would lie outside the proper scope of class treatment. ${ }^{81}$

\section{Policy Considerations Mandating the Estimation of Individual Claims by Courts Other than the Bankruptcy Court}

If common issues in the Manville case may be disposed of in a class format, even if different classes must be certified for several different states, such treatment would be preferable to individual adjudication: it would save time, prevent inconsistent judgments, and better conserve the assets of the going concern by reducing litigation costs. ${ }^{82}$ Yet even if some issues

${ }^{79}$ Certification of discrete issues within a case is permitted by FED. R. Crv. P. $23(\mathrm{c})(4)$.

$808_{3}$ F.R.D. at $386-87$.

81 See FED. R. CIV. P. 23 advisory committee note ("In these circumstances [a mass accident resulting in injuries to numerous persons] an action conducted nominally as a class action would degenerate in practice into multiple lawsuits separately tried."), reprinted in 39 F.R.D. 95, I03 (Ig66).

82 Minimizing litigation costs is of particular concern in the Manville case, because Manville's defense costs will be deducted from the already limited assets available to the asbestos claimants. The calculations presented at supra note 5 I demonstrate the serious danger that litigation costs would consume most of the compensation fund and leave little money for the plaintiffs. The ideal estimation procedure from the standpoint of limiting Manville's defense costs would seem to be the estimation of individual claims by a panel of experts in the bankruptcy court rather than individual estimation in numerous other courts. In defense of the plan proposed in this Note, 
may be treated in a class action format, those issues would more appropriately be litigated in courts other than the bankruptcy court. This conclusion is suggested by a consideration of the policies underlying the doctrine of pendent jurisdiction and the right to trial by jury.

x. Analogy to Pendent Jurisdiction. - Northern Pipeline problems aside, there is no question that the Manville bankruptcy court has the power to exercise jurisdiction over the asbestos-related claims before it. ${ }^{83}$ In bankruptcy proceedings, the policy of providing the debtor complete relief by disposing of all possible creditor claims pressures the court to exercise jurisdiction to the greatest extent possible. Nevertheless, the court's equitable powers free it to choose not to exercise jurisdiction over particular proceedings within a chapter II case when the court believes such abstention to be consonant with the aims of the Bankruptcy Code and in the interests of justice. ${ }^{84}$ The unique aspects of the Manville case invite the

however, it should be pointed out that, even though the use of experts would reduce Manville's defense costs, such a procedure could actually increase the total litigation costs in the asbestos suits by forcing plaintiffs into multiforum litigation. See infra pp. I $138-39$.

Moreover, the example presented at supra note $5 \mathrm{r}$ assumed that defense costs would remain as high as they are currently. Under the plan proposed in this Note, however, two factors would make both plaintiffs' attorneys and defense attorneys more willing to settle out of court, and thus would contribute to reduced defense costs. First, because plaintiffs would be limited to recovering less than 100\% of their judgments, their lawyers' contingent fees would be reduced proportionately. This reduction in contingent fees would in turn reduce the number of claims that plaintiffs' lawyers would be willing to litigate fully, and would create added pressure on those lawyers to settle out of court. Second, the defense litigation would almost certainly be placed in the hands of a court-appointed master, because the establishment of a fixed ceiling on Manville's liability would eliminate Manville's incentive to defend the fund. Because he would not be motivated by such concerns as avoiding adverse publicity for the company, the master would have no reason to adopt the allegedly overaggressive litigation strategy that Manville has pursued for several years, see Application for Dismissal of Cases or Abstention, supra note 22, at ro-II.

\$3 See 28 U.S.C. \$ 147 I (Supp. V 198I); see also Williams v. Austrian, 33I U.S. 642 (1947) (holding that jurisdiction of article III reorganization courts under chapter $\mathrm{X}$ of Bankruptcy Act of $\mathrm{I} 898$ extended even beyond creditors' claims to plenary suits brought by trustee). Although 28 U.S.C. $\$_{1471} 1$ will not take effect officially until April I, 1984, when the new bankruptcy court system will come into being, its terms are expressly incorporated by the BRA provision governing bankruptcy jurisdiction in the interim, Pub. L. No. 95-598, $\$_{405}, 92$ Stat. 2549 , 2685 (I978) (not codified).

s4 See Bohack Corp. v. Borden, Inc. (In re Bohack Corp.), 599 F.2d 1 r6o (2d Cir. I979); Jewel Terrace Corp. v. Kew Gardens Tenants League (In re Jewel Terrace Corp.), 3 Bankr. 36 (Bankr. E.D.N.Y. Ig80); 28 U.S.C. \$ 147 I(d) (Supp. V I98I). Because 28 U.S.C. $\$$ I 47 I(a) (Supp. V I 88 I) grants the bankruptcy courts exclusive jurisdiction over title II cases, the bankruptcy court would not be permitted to abstain from the entire Manville reorganization case. However, because the asbestos claims are not reorganization cases in themselves but rather are "particular proceeding[s]" 
exercise of such discretion, because the bankruptcy court may leave the determination of individual claims to other courts without compromising the complete relief of the debtor.

Under United Mine Workers v. Gibbs, ${ }^{85}$ even when a federal court has the power to exercise pendent jurisdiction over state claims, it should decline to do so unless such exercise is justified by "considerations of judicial economy, convenience and fairness to litigants." 86 Because the bankruptcy court's power to exercise jurisdiction over the asbestos claims derives not from pendent jurisdiction but rather from the Bankruptcy Code itself, ${ }^{87}$ the Manville court cannot mechanically apply pendent jurisdiction doctrine to free itself from individual estimation of the claims. However, insofar as the Manville court is a federal court with a choice whether to exercise jurisdiction over state law claims in the absence of diversity of citizenship, its situation is close enough to that of a federal court exercising pendent jurisdiction that it might look to pendent jurisdiction policies for guidance.

One can imagine situations in which a bankruptcy court's estimation of many individual claims in a Manville-type case might not hinder judicial economy. For instance, if Manville were the sole defendant in the asbestos claims, the bankruptcy court's exercise of jurisdiction over those claims would have the effect of moving them into a different forum without increasing the amount of litigation. Similarly, if there were numerous codefendants for each asbestos claim but all were in bankruptcy court, the bankruptcy court could consolidate the litigation even if the various codefendants were in different bankruptcy courts. ${ }^{88}$

The facts of the Manville litigation do not fit these patterns. Nearly every asbestos claim against Manville also involves a number of codefendant asbestos manufacturers. ${ }^{89}$ Because of the multiplicity of defendants, most of the various state and federal courts in which the pending claims have been filed will

\footnotetext{
"arising in or related to" the overall reorganization case, 28 U.S.C. $\$$ I47I(d) (Supp. V I 981 ), the bankruptcy court may abstain from hearing the claims "in the interest of justice." Id.; see S. REP. No. 989, supra note 16 , at $153-54$, reprinted in 1978 U.S. CODE CONG. \& AD. NEwS at 5939-40; H.R. REP. No. 595, supra note 3, at $445-46$, reprinted in I978 U.S. CODE CONG. \& AD. NEWS at 6400-or.

${ }^{85} 383$ U.S. 715 (1966).

${ }^{86} I d$. at 726 .

${ }^{87}$ See Bankruptcy Reform Act of 1978 , Pub. L. No. 95-598, $\$ 405,92$ Stat. 2549, 2685 (not codified) (governing bankruptcy jurisdiction until April I, I984, when 28 U.S.C. $\$$ I47I (Supp. V I98I) officially takes effect).

88 See 28 U.S.C. \$ 1475 (Supp. V I98I).

${ }^{89}$ See, e.g., In re Related Asbestos Cases, 23 Bankr. 523 (N.D. Cal. 1982) (22 defendants).
} 
continue to hear cases against the other defendants even if Manville's liability is determined by the bankruptcy court. ${ }^{90}$ Therefore, if the bankruptcy court were to estimate claims individually, a sort of mass mitosis would occur, splitting each of the 16,500 claims into two components and requiring two separate courts to consider each claim. The result would be a multiplicity of suits and a massive waste of judicial resources. ${ }^{91}$ Even if the Manville court were to treat the asbestos claims as a class action rather than as individual actions, the duplication of efforts by other state and federal courts would be substantial.

Considerations of "fairness to litigants" 92 also weigh heavily against the estimation of individual claims by the bankruptcy court. The estimation of each individual claim would place an intolerable burden on the plaintiffs, who would be forced to pursue their suits simultaneously in two separate forums, perhaps thousands of miles apart. Moreover, the plaintiffs would be faced with the prospect of inconsistent judgments on a single claim. Plaintiffs winning jury verdicts against Manville's codefendants would understandably feel cheated if a panel of experts in the bankruptcy court gave them either no award against Manville or an award much smaller than they could have expected from a jury.

Gibbs further emphasized that federal courts should be particularly hesitant to exercise jurisdiction when "state issues substantially predominate, whether in terms of proof, of the scope of the issues raised, or of the comprehensiveness of the remedy sought."93 In the asbestos cases, state tort issues clearly predominate. Admittedly, bankruptcy courts have experience in applying state law because they regularly allow and estimate state law contract and tort claims. Nevertheless,

90 Once the automatic stay went into place and halted all litigation involving Manville and UNR, the codefendants in the asbestos cases attempted to have the litigation stayed for them also. As of December I, I982, at least 38 courts had ruled that the automatic stay affects only Manville and UNR and that litigation must proceed against the other codefendants. See, e.g., In re Related Asbestos Cases, 23 Bankr. 523 (N.D. Cal. 1982); In re UNR Indus., 23 Bankr. I44 (Bankr. N.D. Ill. 1982). As of the same date, approximately 14 other courts had stayed proceedings against all codefendants, see, e.g., Asbestos Cases, No. $78-98$ (D. Me. Sept. 21 , 1982), although a number of those stays were only temporary, pending a full briefing and argument on the issue, see, e.g., Bowman v. Johns-Manville Sales, No. C-2-8I-I492 (S.D. Ohio Aug. 5, I982).

91 Of course, the resolution that this Note suggests would not free the bankruptcy court from all duties with respect to the disposition of individual claims. The bankruptcy court would be freed, however, from managing litigation that is wholly duplicative of litigation in progress in other courts.

92 Gibbs, 383 U.S. at 726 .

93 Id. 
whenever a bankruptcy court applies state law, it must secondguess state courts and apply state law as it believes the highest state court would. ${ }^{94}$ Such determinations always involve the possibility of error and thus should not be made more often than is necessary. When state law questions determine the rights of many thousands of litigants, considerations of comity should cause a bankruptcy court to be doubly hesitant to exercise its jurisdiction. ${ }^{95}$

2. Right to Trial by Jury. - Like the policies underlying pendent jurisdiction, the right to trial by jury suggests that the Manville bankruptcy court should leave the estimation of individual claims to other courts. Typically, the asbestos claims are brought under state product liability statutes and negligence regimes that confer a right to trial by jury. ${ }^{96}$ In bankruptcy court, however, the claimants probably enjoy no such right. The leading case under the old Bankruptcy Act, Katchen $v$. Landy, ${ }^{97}$ recognized that litigants had no right to a jury trial, because adjudication of their claims fell within the "summary" jurisdiction of the bankruptcy court as opposed to the plenary jurisdiction of another federal or state court. ${ }^{98}$ The asbestos plaintiffs' claims similarly fall within the "summary" jurisdiction category; they are claims brought against assets of the estate that are currently under control of the bankruptcy court. ${ }^{99}$ Although it is disputed whether the draft-

${ }_{94}$ See II U.S.C. $\$$ 502(b)(I) (Supp. V I98I).

95 See Jewel Terrace Corp. v. Kew Gardens Tenants League (In re Jewel Terrace Corp.), 3 Bankr. 36 (Bankr. E.D.N.Y. I980); S. ReP. No. 989, supra note I6, at 154, reprinted in I978 U.S. CODE CONG. \& AD. NewS at 5940; H.R. REP. No. 595, supra note 3 , at $5 \mathrm{I}$, reprinted in 1978 U.S. CODE CONG. \& AD. NEWS at 6012.

It may be that most of the asbestos claims were originally filed in federal district courts rather than state courts. Nevertheless, the competence and comity arguments advanced in this Note still weigh in favor of the bankruptcy court's leaving the estimation of individual claims to the federal district courts in which the claims were filed. The federal district court for the Northern District of Illinois, for example, is more experienced in construing Illinois tort law than is the bankruptcy court for the Southern District of New York.

96 See, e.g., Nolan v. Johns-Manville Asbestos, 85 Ill. 2d I6I, 42 I N.E.2d 864 (I98r) (action brought under Mllinois strict products liability theory); Beshada v. JohnsManville Prods. Corp., 90 N.J. I91, 447 A.2d 539 (I982) (action brought under New Jersey strict products liability theory).

97382 U.S. 323 (1966).

98 Id. at $33^{6-37}$; see Belfance v. Sizzler Family Steak Houses (In re Portage Assocs.), I6 Bankr. 445, 447 (Bankr. N.D. Ohio 1982); Levy, Trial by Jury Under the Bankruptcy Reform Act of 1978 , 12 CoNN. L. REv. 1, 3-5 \& n.12 (1979). For discussions of the distinction between summary and plenary jurisdiction, see $\mathrm{J}$. MACLACHLAN, HANDBOOK OF THE LAW OF BANKRUPTCY 212 (1956); 13 C. WRIGHT, A. Miller \& E. Cooper, Federal Practice and Procedure § 3570 (I975); Levy, supra, at 3 n.I2.

99 See Booth v. Manufacturers Hanover Trust Co. (In re Cafes Internationale, Ltd.), I3 Bankr. 155, 158 (Bankr. S.D.N.Y. I98I). 
ers of the Bankruptcy Reform Act intended to preserve, or instead to eliminate, the summary-plenary distinction for purposes of determining the right to trial by a jury, ${ }^{100}$ most courts have continued to apply the distinction. ${ }^{101}$

The effect of estimating individual claims in the bankruptcy court would thus be to deny plaintiffs the juries to which they would be entitled in other courts. This denial cannot be justified by the policy underlying the absence of a jury right in the typical bankruptcy case - freeing the bankruptcy court to carry out its mission quickly and efficiently. ${ }^{102}$ In the Manville case, the bankruptcy court would promote neither efficiency nor any other policy of the Bankruptcy Code by estimating individual claims itself.

\section{CONCLUSION}

The new Bankruptcy Code gives bankruptcy courts broad discretion to dismiss reorganization petitions filed in bad faith. When a solvent and healthy corporation files a reorganization petition based on massive but speculative tort liability, the court should inquire, on motion of a party in interest, into the financial condition of the company and the validity of its projections of liability. If creditors are able to show that the debtor's projections are inaccurate and that the debtor corporation does not face insolvency in the foreseeable future, the court should dismiss the petition under section III2(b) of the Bankruptcy Code.

If the creditors fail to discredit the corporation's projections and it appears that the purposes of the Code would be served by the filing, the bankruptcy court should entertain the petition. Nevertheless, the court should not undertake the estimation of each creditor's individual claim. Rather, to promote judicial economy, comity, and fairness to the plaintiffs, and in

100 Compare Belfance v. Sizzler Family Steak Houses (In re Portage Assocs.), I6 Bankr. 445 (Bankr. N.D. Ohio I982) (II U.S.C. \$ 1480 (Supp. V I98I) preserves the jury right system of the Bankruptcy Act), with Pinson v. Reynolds (In re First Fin. Group, Inc.), II Bankr. 67 (Bankr. S.D. Tex. I98I) (II U.S.C. \$ I480 (Supp. V I98I) discards the summary-plenary distinction that determined jury rights under the Bankruptcy Act), and Brown v. Frank Meador Buick, Inc. (In re Frank Meador Buick, Inc.), 8 Bankr. 450 (Bankr. W.D. Va. 198I) (same). For a general discussion of the two competing interpretations of II U.S.C. \$ 1480 (Supp. V I98I), see Levy, supra note 98 .

101 See, e.g., Belfance v. Sizzler Family Steak Houses (In re Portage Assocs.), 16 Bankr. 445, 447 (Bankr. N.D. Ohio I982); Zimmerman v. Mozer (In re Mozer), ro Bankr. I002 (Bankr. D. Colo. I98I); G.S.F. Corp. v. Inleasing Corp. (In re G.S.F. Corp.), 7 Bankr. So7 (Bankr. D. Mass. 1980).

${ }_{102}$ See Katchen v. Landy, 382 U.S. 323, 339-40 (1966). 
order not to interfere with the plaintiffs' right to trial by jury under state law, the bankruptcy court should limit itself to estimating the corporation's total liability, placing a ceiling on that liability, and establishing a compensation fund for the plaintiffs. The plaintiffs should be allowed to pursue their claims in the state and federal courts in which the claims were originally filed and then to return to the bankruptcy court to execute their judgments on a pro rata basis against the compensation fund. 